\begin{tabular}{c} 
Volume and Issues Obtainable at Center for Sustainability Research and Consultancy \\
Journal of Accounting and Finance in Emerging Economies \\
ISSN: 2519-0318 ISSN (E) 2518-8488 \\
Volume 7: Issue 1 March 2021 \\
CSRC \\
Journal homepage: www.publishing.globalcsrc.org/jafee \\
\hline
\end{tabular}

\title{
The Relationship Between Corporate Diversification and Tax Avoidance: Empirical Evidence from the Emerging Economy of Pakistan
}

\author{
${ }^{1}$ Muhammad Tasnim Khan, ${ }^{2}$ Muhammad Mudassar Anwar, ${ }^{3}$ Muhammad Husnain, \\ ${ }^{1}$ University of Management \& Technology (UMT), Lahore, Pakistan, tasnim.khan@umt.edu.pk \\ ${ }^{2}$ Assistant Professor, Department of Commerce, University of Kotli Azad Jammu and Kashmir, Kotli, \\ Pakistan, mudassarswati@yahoo.com \\ ${ }^{3}$ Assistant Professor, Department of Business Administration, University of Sahiwal, Sahiwal 57000, \\ Pakistan,m.husnain@uosahiwal.edu.pk

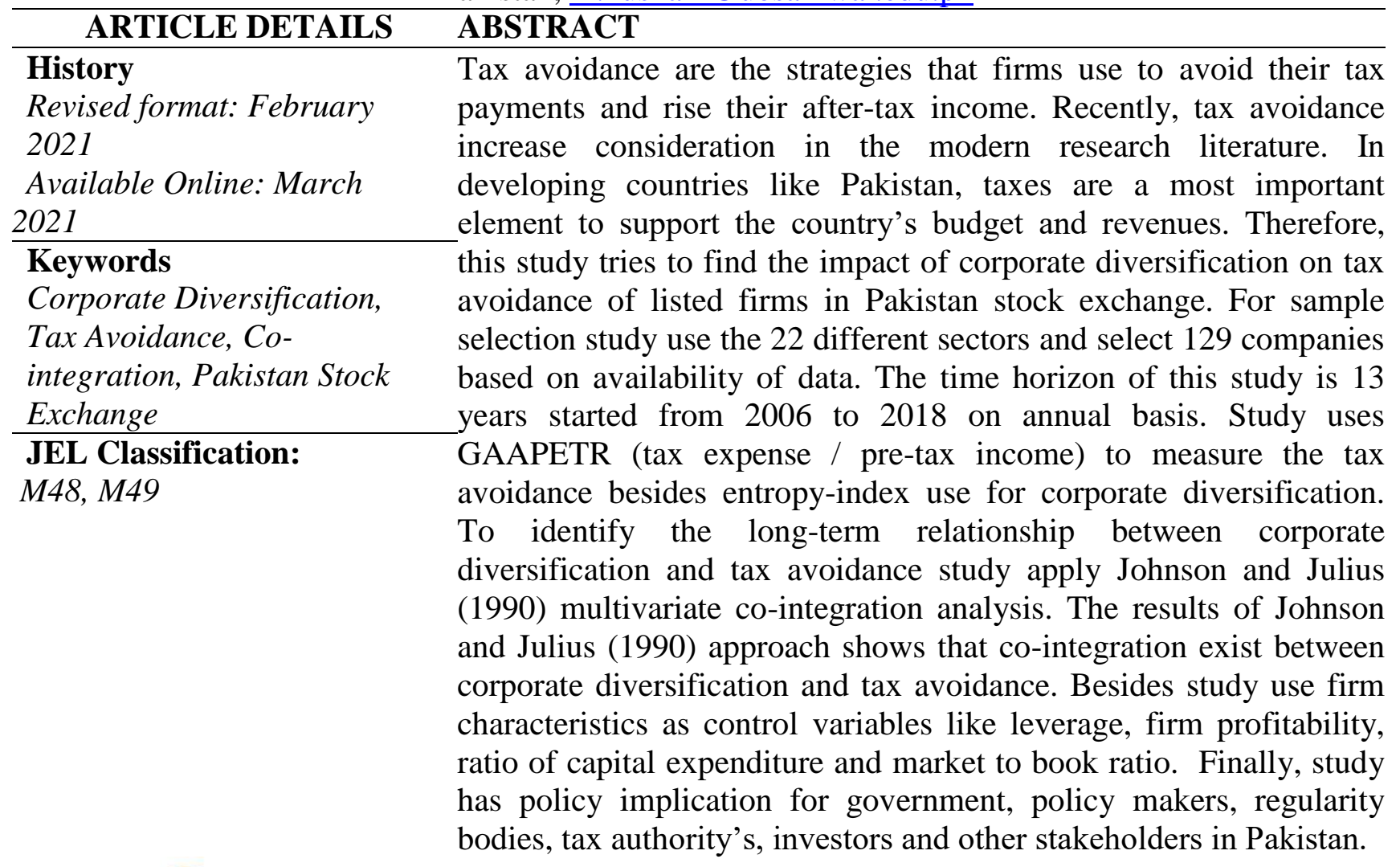

\section{OPEN ACCESS}

(C) 2020 The authors, under a Creative Commons AttributionNonCommercial 4.0

Corresponding author's email address: m.husnain@uosahiwal.edu.pk

Recommended citation: Khan, M. T., Anwar, M. M. \& Husnain, M. (2021). The Relationship Between Corporate Diversification and Tax Avoidance: Empirical Evidence from the Emerging Economy of Pakistan. Journal of Accounting and Finance in Emerging Economies, 7(1), 35-52

\section{Introduction}

In corporate finance literature, tax avoidance is consider most important problem and has gained vast interest in political and academic debates (Huseynov, \& Klamm, 2012). An opinion established by Deasi and Dharmapala, (2009) that tax avoidance has increased considerably in the modern research literature 
and the same argued by Gallemore and Labro, (2015). Tax avoidance states to a variety of tax planning strategies and practices aimed to reduce taxable income. Companies use these strategies to avoid their tax and raise after-tax income without violating tax laws (Wilson, 2009 \& Lisowsky, 2010). In present research literature about big companies like Facebook, Starbucks (Davis, Guenther, Krull, \& Williams, 2015) in addition to most important financial setbacks like Enron and Tyco (Wilson, 2009) have given the importance that in current situation of developed countries business environment, tax avoidance considered as most important phenomena.

Tax avoidance is not an illegal activity but an unethical practice to get benefit by an individual or business. In developing countries like Pakistan tax avoidance, create significant, influence in public revenues that meet their budgetary demands (Picur \& Riahi-Belkaoui, 2006). Government has imposed higher tax penalties to increase its tax revenue (Mashaiekhi \& Seyyedi, 2015). A New York Time report (NYT) paper exposes that the biggest organization of America compensated zero taxes going on \$14.2 billion profits, yet this one really got tariff acknowledgements of $\$ 3.2$ billion (Hundal, 2011) comparatively requested that laborers create compensations. It has additionally inspected that $60 \%$ of American biggest organizations do not pay a considerable amount of taxation (Braithwaite, 1998). Lanes and Richardson, (2011) investigated 58 Australian companies and organizations were suspects of tax avoidance. Furthermore, the efficient mechanism of tax collection is most important because tax revenue is required to meet the development and non-development expenditures.

Kenny, (2002) explores that the large numbers of people did not paying tax, which highly damage the social capital and community ethics. While researchers (Chircop, Fabrizi, Ipino, \& Parbonetti, 2018) find that the firm are socially responsible for the tax payments, with these practices can engage social capital with less tax avoidance practice. Additionally, the results show tax avoidance has risen in both absolute and relative terms with increasing the minimum tax rate. One more essential item, which may affect tax avoidance, is an underground economy. Researchers investigate underground economy is treated as equal to the amount of tax avoided. Sam, (2010) examined the fundamental purpose behind tax avoidance is that most of the people do not report their incomes to the tax authorities, thus creating tax collection problems. Researcher also explores that the underground economy and tax avoidance are related but they are not identical.

It can be said, there are many internal and external firms specific factors that affect corporate tax avoidance as research and development, intangible assets, capital intensity, profitability, leverage and firm size (Annuar, Salihu, \& Obid, 2014; Mulyadi \& Anwar, 2014; Duan, Ding, Hou, \& Zhang, 2018). Beside that corporate governance factors like CEO ownership, family ownership, CSR, overseas proprietorship and women on board affect corporate tax avoidance (Landry, Deslandes, \& Fortin, 2013; Armstrong, Blouin, Jagolinzer, \& Larcker, 2015). Corporate diversification another factor that affect tax avoidance in emerging countries. It is a surprising there are not much studies on corporate diversification and tax avoidance in emerging countries like Pakistan.

Corporate diversification view of tax avoidance has added academic adhesion and has created research interest in financial literature. Corporate diversification is a strategy that companies use to diversify their businesses (Zheng, 2017). Researchers link diversification with a range of benefits such as greater market power, efficient allocation, good factor of production, best utilization of existing resource and reduce performance variability (Chakrabarti, Singh, \& Mahmood, 2007). Corporate diversification may provide a platform for examining, testing and analyzing the determinants of tax avoidance. Researchers also explore that diversified industries have more possibilities to change prices in multiple business segments or areas and engage in tax avoidance actions (Zheng, 2017). Researcher investigate companies diversified in different segments might engage lower level of tax avoidance practices rather than standalone firms do (Zheng, 2017). Hanlon and Heitzman, (2010) examined prices of goods and services that transfer from one segment to another segment of the same company. The transfer prices are used to allocate profits across divisions for tax purposes (Simth, 2002). Therefore, no attention has been focus in the relationship between corporate diversification and tax avoidance in emerging economy.

This study investigate the relationship between corporate diversification and tax avoidance in emerging 
economies like Pakistan. Prior research investigates that no significant difference in tax aggressiveness $\&$ tax avoidance found in literature (Richardson et al., 2015). Some researcher described different meaning for defining these terms and some provide same meaning of both (Richardson, Lanis, \& Taylor, 2015). On the other hand, many researcher analyze the corporate diversification with different domes such as corporate diversification and firm performance (Bhatia \& Thakur, 2018) ownership structure, corporate diversification and capital structure ( $\mathrm{Su}, 2010)$, corporate diversification and earning management (Khanchel, Mehdi, \& Seboui, 2011) then effects of corporate diversification on productivity (Schoar, 2002). Besides Zheng, (2017) examine the relationship among corporate diversification and tax avoidance in United State companies prospective. Therefore, this study investigate the long- run relationship between corporate diversification and tax avoidance developed economies to emerging economies like Pakistan, China, India. On the other hand, it extend the debate on the association between company diversification and tax avoidance. This study also provide important policy implications for regulators concerning the issue of corporate diversification and corporate taxes avoidance. This study may provide assistance to the federal board of revenues (FBR) to take initiative that relates certain mechanisms to increase tax payments.

\section{Theoretical Background}

The idea behind this research is to explore the relationship of corporate diversification on the practice of tax avoidance based on agency theory. Details of theory is as below.

\subsection{Agency Theory}

The Berle and Means, (1932) and Smith, (1776) emphasized the separation mechanisms of proprietorship and control. The control separation between principal \& agent create the agency problem (Berle \&Means, 1932). The theory explains the relationship among principal-agent, shareholders and managers (Jensen \& Meckling, 1976). The shareholders or owners of the companies select directors and CEOs for their business on the behalf of the owners. Shareholders and managers are two separate entities in the organizations and have different interests. Owners expect the managers' act according to their interest and wealth, but the problem arises when managers act in their own interest and benefits instead of increase shareholder's wealth. The interest of owners is to improve the firm's value, which ultimately increases the shareholder's wealth, alternatively manager's emphasis on their self-interest and put their personal interest and benefits. The nature and degree of agency problems can affect the level of tax avoidance. Researchers call for more investigations in the direction of corporate tax avoidance in framework of agency conflicts (Lanis \& Richardson, 2012; Desai \& Dharmapala, 2006; Scholes, Wolfson, Erickson, Maydew, \& Sheylin, 2005).

In previous studies explored the relationship among corporate diversification discounts (share of a firm when issued at a price lesser than the face value of share called diversified discount) and corporate governance and investigate the agency conflict among shareholders (Principal) and managers (Agents) (Aggarwal \& Samwick, 2013). Much researcher document that firm, which are diversified have weak corporate governance mechanism than stand-alone firms (Hoechle, Schmid, Walter, \& Yermack, 2012). Desai and Dharmapala, (2006) investigate weak corporate governance destroy the relationship among shareholders (Principal) and managers (Agents) and it leads firm managers to be less aggressive about increasing firm value through tax avoidance. Weaker corporate governance implies that diversified firms might engage in fewer tax avoidance than stand-alone firms Zheng, (2017).

\section{Related Literature Review and Hypothesis Development}

In this section included related literature and development of hypothesis beside that this section also comprise conceptual framework of the study.

\subsection{Corporate Diversification and Tax Avoidance}

There are limited literature available only one study that analysis the relationship between corporate 
diversification and tax avoidance from Zheng, (2017) as Unstated State companies proactive. Corporate diversification is a strategy that companies use to diversify their businesses (Zheng, 2017). Under the umbrella of corporate diversification, several studies conducted such as Matsusaka, (2001) found that diversification is a procedure by which corporations search for new uses of their organizational capabilities. Denis and Sarin, (1997) documented that the corporate diversification is negatively influencing on equity ownership of outside the stakeholders. In view of emerging markets, corporate diversification is more valued as compared to stand-alone firms working in comparable industries, which support for diversification premium (Akben Selçuk 2015). Diversified firms have comparatively less earning problems than stand-alone firms (Mehdi \& Seboui, 2011). Bhatia and Thakur, (2018) studied on corporate diversification in Indian companies and found that the relationship among diversification and performance turns out to be firmly significant and positive after controlling the issues of endogeneity. Beside, Olibe, Rezaee, Flagg and Ott, (2019) explored the relationship between equity and firm diversification in US industry and found that US diversified firms have high equity value.

Any firms have different characteristics such as stand- alone or diversified firms and those characteristics casus variations of tax avoidances. Firm size and R\&D expenditure that factors affect the tax avoidance strategies. Firm size positively influenced in between corporate effective tax rates (Zimmerman, 1983). Spending on R\&D expenditure can engage tax avoidance activities (Zheng, 2017). As a results of less spending on R\&D expenditure and high economy of scale diversified firm have less tax avoidance rather than stand- alone firms. Nevertheless, corporate diversification adds new ideas in present research literature with tax avoidance applies. Therefore, in this study examine the relationship of corporate diversification and tax avoidance strategies. According to past research, this study develop a hypothesis.

$\mathbf{H}_{\mathbf{1}}$ : There exist significant relationship between corporate diversification and tax avoidance.

\subsection{Leverage and Tax Avoidance}

Leverage represents an organization's use of debt amount to finance its assets, when a company invests in property or project from debt financing rather than equity, it means the company has high leverage, also mentioned it by Richaradson and Lanis, (2007) that greater debt to equity ratio has tendency to be more efficient in reducing tax liabilities. Further, he explained that high leverage firms less participate in tax avoidance because they already have tax shield advantage to debt financing. Finally, there is a substitution results between level of debt and high leverage tax shields benefits. Researcher investigate substitution effects and hypothesis when firms engage in tax shelter activities they use less debt (Graham \& Tucker, 2006). Another study provides unpredictable results; leverage is positively related with corporate tax avoidance. Researcher documented interest expenses of debt above a certain level specified by tax laws cannot be tax deductible (Koh, 2007; Kweon, Kang, Kim, \& Kim, 2009). These results propose that using high leverage above a certain limit rather increase company's tax costs and thus, firms with high leverage ratio are likely avoid taxes. Because of previous research, this research has formulated the subsequent hypothesis.

$\mathrm{H}_{2}$ : There exist significant relationship between leverage and tax avoidance. 


\subsection{Firm Profitability and Tax Avoidance}

In recent year's business strategies has change due to increase in competition. Firm profitability means companies capable of generating profit from its operations (Shin \& Soenen, 1998; Lazaridis \&Tryfonidis, 2006; Falope \& Ajilore, 2009). Whereas, almost in all cases tax avoidance provides the organization with short-run financial advantages. On the other hand, leads to marketing and production drawbacks, in the log-run period its leads to reduction of business competitiveness and therefore, financial losses reduction of profit and profitability of the organizations (Bogoviz, 2019). Organizations are interested to improve their profitability through tax savings, thereby improving the operating performance. Researchers investigated the demand for tax avoidance practice is additionally likely affected by profitability and create larger business profits and benefits from corporate tax avoidance. In the event that there is potentially grater tax, it is acceptable otherwise that tax be payable (McClure, Lanis, Wells, \& Govendir, 2018). Previous finance researcher shows that corporate tax aggressiveness is the way for high profitability the organization in many attributes (Rego \& Wilson, 2012). Firm profitability also associated with ETRs Gupta and Newberry, (1997) investigated that the subordinate ETRs are significant by lesser productivity, however greater influence with investment concentration. Besides, corporate tax management adds to the profitability of business and optimization of tax liabilities (Kirina \& Nazarova, 2017). Firms with higher return on assets have lower effect to participate in higher corporate tax avoidance (Richardson et al., 2013). Consistent with the literature this study proposes the following hypothesis.

$\mathbf{H}_{3}$ : There are significant relationship between firm profitability and tax avoidance.

\subsection{Capital Expenditure and Tax Avoidance}

Researchers use capital expenditure as explanatory variables for example (Morck, 2005, Desai \& Dharmapala, 2008). Husevnov and Klamm, (2012) also found two effects of capital expenditure on effective tax rate ETR. When organization have higher capital expenditure the result of higher GAAPETR. It means firm has more tax payments but lower Cash effective tax rate ETR. These changing effect might be connected the long term issue like long time deprecation period. This results also reliable with (Armstrong et al., 2011) he examined the inverse relationship between the new investment that comprises capital expenditure and tax avoidance strategies. In a view of corporate diversification Rajan et al, (2000) reported it might be conceivable the companies diversified with multiple segments have more funds, it's means a firm has more plant, machinery and equipment because it's cost of capital is lower. Consequently, it very important to further deduct the average industry adjusted capital expenditure to assets ratio be around the sections of the firms. Finally, Capital expenditure measure as the ratio of capital expenditure to sale (Zheng, 2017). Rego and Wilson (2012) use capital expenditure as control variable and found that organizations with bigger capital expenditure escape exercise-relating tax. Consistent with the literature, researcher develop a hypothesis.

$\mathbf{H}_{4}$ : There are significant relationship between capital expenditure and tax avoidance 


\subsection{Market to Book Ratio and Tax Avoidance}

It is a monetary valuation, generally measure as the market value of a firm's equity (MVE) divided by the book value of equity (BVE). MBR analysis of firm's current market value comparative to its book value. In prior research MBR use as control variable and also evidenced by (Dyreng, Hanlon, \& Maydew, 2008; Rego \& Wilson, 2012; Kang, 2013; Huseynov \& Klamm, 2012; Masripah, Diyant, \& Fitriasari, 2017; Chircop et al., 2018; Olibe et al., 2019). Researchers also examined market to book ratio with debt financing cost, those firm have high market to book ratio that firms borrow more and lower debt-financing cost (Chen, \& Zhao, 2006). Olibe et al., (2019) claimed that MBR use to measure the firm growth. Olibe et al., (2019) examined firm growth with long term debt as those firms that have high growth opportunities not need to corrective role of debt and create restrict problems linked with high free cash flows and consequently these firms less long term debt. In past research market to book ratio use as proxy for agency problem (Deng, Elyasiani, \& Mao, 2007). Researcher examined those firms with higher growth options that have high agency problem (Myers, 1977). Researchers also investigated the MBR value control the firm growth opportunities. This statement also documented form Chen et al., (2010) analyzed that organizations had extraordinary firm growth opportunities make acquisitions with corporate tax avoidance focal points. Considering the previous research literature this study investigates the hypothesis.

$\mathbf{H}_{5}$ : There are significance relationship between market to book ratio and tax avoidance.

\subsection{Data Description and Research Methodology}

The study based on convenient sampling which are the type of non-probability sampling. The initial sample of this study is 200 companies form 22 sectors in Pakistan stock exchange. Since financial companies, as if banks and insurance institution have different and difficult structure of profit maximization and corporate tax activities so in this study excluded the financial sector. Moreover, the companies for which data were not available and those companies are delisted, acquired/merged, liquidated, or naturally replaced by the end of the financial year 2018 excluded in the sample. On the other hand a further 10 companies were excluded as outliers because these companies have 20 standard deviations away from the mean on the measurement of tax avoidance. After excluding the financial sectors and firms with unavailability of data, the final sample is 129 non-financial Pakistani listed companies are available for this study. The sample period spans of the study is 13 years' annual bases from 2006 to 2018. Data is collected form annual reports of the companies, web sites of the companies, and through state bank balance sheet analysis. These sources consider secondary data are as reliable for Pakistani companies.

\subsection{Measurement of Variables}

The measurement of all items are in this research were embraced from established and validated proxies.

\subsection{Tax Avoidance}

Researchers investigated all measurement have different limitations which makes difficult to tax prevention (Hanlon \& Heitzman, 2010; Lisowsky, 2010). This study relies one measurement of corporate tax avoidance that is GAAP ETR operative tax rates (Dyreng et al., 2008, 2010; Minnick \& Noga, 2010). ETR have generally use in the literature for apprehending and associating the tax encumbrance of firms and industries (Fullerton, 1984; Dyreng et al., 2008). The GAAPETR is calculated with ratio of tax expense divided by the pre-tax income (EBT) (McClure et al., 2018). Furthermore, Dyreng et al., (2008) documented that this measures capture the variant in company tax avoidance.

$$
\text { GAAPETR }=\frac{\text { Tax Expense }}{\text { Pre tax income }}
$$




\subsection{Corporate Diversification}

Corporate diversification measured using Jacquemin and Berry, (1979) entropy-index. Entropy index proposed as measure of randomness of variables and income inequality in a population (Shorrocks, 1980). In addition, this index derive as biodiversity so entropy index also been proposed as measurement of diversity (Pielou, 1966). This study follow the previous researcher's measures entropy-index. The total degree of diversification DIV from the entropy index is a continuous measure and is determined as pursues.

$$
D I V=\sum_{i=1}^{N} P i * \ln \left(\frac{1}{P i}\right)
$$

\subsection{Leverage}

In this research, firm leverage (LEV) is measure through the long-term debt (DEBT) divided by the total assets (TA). This measurement is also use in previous research by (Sarwar, B., Xiao, M., Husnain, M., \& Naheed, R. 2018; Mohanadas, Abdullah, \& Pheng, 2019; Borghesi et al., 2019).

\subsection{Firm Profitability}

$$
L E V=\frac{D E B T}{T A}
$$

There are many methods to measure the firm profitability. In this research, FP measured by the ratio of EBIT to SALE (Zheng, 2017) also evidences this measurement for firm profitability.

\subsection{Capital Expenditure}

$$
F P=\frac{E B I T}{S A L E}
$$

Capital expenditure use as control variable and measured by the capital expenditure ratio that is $\mathrm{CE}$ to SALE and this measurement also consistent by (Zheng, 2017; Desai \& Dharmapala, 2009).

\subsection{Market to Book Ratio}

$$
C E=\frac{C E}{S A L E}
$$

This study MBR used as control variable and measure as MVE to BVE and finally take natural log of final answer (Zheng, 2017). This measurement consistent with previous researchers like (Masripah et al., 2017; Sarwar, Xiao, Husnain, \& Naheed, 2018).

$$
\text { Market to Book Ratio }(M B R)=\ln \left(\frac{M V E}{B V E}\right)
$$

\section{Research Methodology}

In this study use time series data to investigate the long-run relationship between corporate diversification and tax avoidance in emerging economies like Pakistan. Against this purposes researcher apply different statistical models describe follows.

Descriptive statistics provide easiest interpretation of the data. It would be very hard to visualize of raw data. Descriptive statistics includes measurement of central tendency and measure of dispersion with show how the data disperse (spread) to mean value. For empirical testing and analysis, different data sets can be used in researchers such as cross sectional data, time series data and panel data. The second type of data set is time series; time series data is data consists of conventional of interpretations the value that a variable taking at dissimilar period. In this research time, series data is used. Furthermore, this type of data is extensively used in management science, epidemiology and econometrics (Shah, Muhammad, Husnain, \& Ali, 2012). On the other hand, to identify multi-colineariality among the variables this study use correlation analysis. Correlation matrix show the direction and strength of variables. Correlation is a statistical method use for estimate the relationship and strength of two quantitative variables. 


\subsection{Unit Root Test}

For JJ (1990) approach one problem, is the stationarity of data. To examine this problem researcher use unit root analysis with two different tests. The first is Augmented Dickey-Fuller (1979) and the second is Phillips - Perron (1988). This study estimate the following equation to test the unit root.

$$
y_{t}=y_{t-1}+\varepsilon_{t} \ldots \ldots \ldots(1)
$$

\subsection{VAR Lag Selection Criteria}

To examine the JJ (1990) approach it is suggest to calculate optimal lag length of data. For this purpose researcher apply vector auto-regression model (VAR) lag selection criteria.

\subsection{Johnson and Julius (1990) Co-integration Analysis}

This study also analysis the long-term relationship among the variables. Therefore, researcher apply JJ (1990) co-integration analysis approach. Co-integration analysis Johnson and Julius (1990) (Shah, A et al., 2012 \& Francis \& Ganeshamoorthy, 2017) is an approach that examined the long run association between the variables with exact time distance. This approach use with two different test first is trace statistics and second maximum-eigen value test.

\subsection{Causality Test}

To inspect the causality between two different variables, researcher apply pairwise granger causality test (Dastgir, S.et al., 2019). Granger causality is a research technique to examine causality between two variables in a data.

\subsection{Variance Decomposition Test}

This study apply variance decomposition test. It's a classical statistical techniques use for large set of variables to uncovering simplifying difficult structure (Anderson T, 2003). Besides, its display the amount of complete information about each variables that explain with other variables (Shah, A et al., 2012).

\subsection{Impulse Response Analysis}

Consequently, this research use IRF impulse response function for display evolution of variables in reaction to a shock in one or more variables along an identified time period (Cheng, Jiao, Chen, \& Xu, 2019). It is a signals or shocks of any dynamic system in response to some external change. Researcher show graphically relationship with tax avoidance and other independent and control variables. This study also understand easier way in the form of IRF equation.

\subsection{Empirical Findings}

$$
\mathrm{xt}=\varphi \mathrm{xt}-1+\mathrm{ut} \ldots \ldots \ldots \ldots(2)
$$

In this section describe all results conclude by using different econometric tools and soft wares beside all brief discussion.

\subsection{Descriptive Statistics}

It includes mean, standard deviation, maximum value and minimum value. These results are generally alien with previous research. Specifically GAAPETR mean value is 1.4507 shows the average tax rate and standard deviation that captures the deviation form variation in the data is range from 0.9029.The average value of DIV corporate diversification is 0.34638 that clearly shows many companies diversified in different countries and sale our products and services to other countries. The standard deviation of corporate diversification is 0.731269 . Descriptive statistics results shows the Leverage 1.94323 with the standard deviation is 2.157526 , rather than the high level of Leverage in the companies are 17.49352 and the lowest level are 0.008808. The market to book ratio (growth value) shows average value 1.55862 with 2.198122 standard deviation. Firm profitability shows 0.00925 of companies and standard deviation that capture the variation is 0.05929 . The capital expenditure 0.30696 it mean capital expenditure is 0.30696 of sale, and 0.731269 of standard deviation. 
Table.1

Descriptive Statistics Analysis

\begin{tabular}{lcccc}
\hline Sr. No. & Mean & $\begin{array}{c}\text { Standard } \\
\text { Deviation }\end{array}$ & Maximum & Minimum \\
\hline Capital Expenditure & 0.30696 & 0.73127 & 9.36185 & 0.00018 \\
Corporate Diversification & 0.34638 & 0.20673 & 0.73559 & 0.00206 \\
Firm Profitability & 0.00925 & 0.05929 & 1.67533 & -0.45010 \\
GAAPETR & 1.45072 & 0.90295 & 5.30351 & 0.00343 \\
Leverage & 1.94323 & 2.15753 & 17.4935 & 0.00881 \\
Market to Book Ratio & 1.55862 & 2.19812 & 18.5648 & 0.00014 \\
\hline
\end{tabular}

\subsection{Correlation Matrix}

The results shows positive relationship between DIV and GAAPETR. It means diversified companies have more tax paid rather than stand-alone companies. Correlation analysis shows that corporate diversification has negative relationship between firm profitability and leverage. Besides that, other variables have positive and negative relationship. In this research table 4.2 reports the multicollinearity checks. Multicollineearity occurs when high correlation exist between two or more variables. These results clearly shows that no multicollinearity within the variables because there are no perfect negative or positive relationship between the variable. The value range of co-relation is +1.0 to -1.0 . The results shows +1.0 it mean perfect positive co-relationship between the variables. Instead, when two variables show -1.0 results. It means two variables are perfect negative relationship. This matrix show the relationship between dependent, control and explanatory variables. Through this matrix, also display the strength and direction of variables.

Table. 2

Correlation Matrix

\begin{tabular}{|c|c|c|c|c|c|}
\hline $\begin{array}{c}\text { Capital } \\
\text { Expenditure }\end{array}$ & $\begin{array}{c}\text { Corporate } \\
\text { Diversification }\end{array}$ & $\begin{array}{c}\text { Firm } \\
\text { Profitability }\end{array}$ & GAAPETR & Leverage & $\begin{array}{c}\text { Market to } \\
\text { Book } \\
\text { Ratio }\end{array}$ \\
\hline
\end{tabular}

Capital

Expenditure

Corporate

Diversification

Firm Profitability

GAAPETR

Leverage

Market to Book

Ratio
1

$-0.2402$

0.20292

$-0.1838$

0.05509

$-0.0726$

0.0707
$-0.0466$

0.03665

$-0.0382$
1

\subsection{Unit Root Test}

A technique use a time series data variables whether that variables are non-stationary. Table 3 
demonstrates the finding of unit root technique. For investigate long run association among that variables in this research researcher apply multivariate co-integration analysis. Before co-integration, approach it have an assumption the stationary of data. They are stationary at level, first or second difference, and they are combine at the same direction.

In this study, use Augmented Dickey-Fuller ADF (1979) and Phillips - Perron PP (1988) test for data stationary. Normally ADF model have error term is independent and that test is homoscedastic. Therefore, to reduce the assumption in this study use Phillips - Perron (1988) test for data stationary. The result ADF (1979) table clearly shows all variables data are stationary at level. On the other hand, in this study also apply Phillips - Perron (1988) test for data stationary analysis level and this result sport the ADF test. The Phillips - Perron (1988) result show all variables data are stationary at level. Besides that, results shows $0.05 \mathrm{p}$ value $(\mathrm{p}<0.05)$ of all variables. All results shows this data are apply for Cointegration analysis.

Table. 3

Unit Root Test

\begin{tabular}{lcccc}
\hline & ADF (Level) & Prob.** & PP (Level) & Prob.** \\
\hline Capital Expenditure & -14.74179 & 0 & -23.4986 & 0 \\
Corporate Diversification & -8.530642 & 0 & -9.92358 & 0 \\
Firm Profitability & -15.43557 & 0 & -41.1557 & 0 \\
GAAPETR & -13.42405 & 0 & -22.2638 & 0 \\
Leverage & -12.8378 & 0 & -20.2549 & 0 \\
Market to Book Ratio & -14.49878 & 0 & -19.5232 & 0 \\
\hline Critical Value & & & & \\
\hline $1 \%$ level & -3.43405 & & -3.43448 & \\
$5 \%$ level & -2.863061 & & -2.86306 & \\
$10 \%$ level & -2.567627 & & -2.56762 & \\
\hline
\end{tabular}

\subsection{VAR Lag Length Criteria}

Consequently, vector autoregressive model VAR comprise lagged values of all model components. VAR is the test for select a proper lag length (how many lags includes) before to apply of Johson Julius (1990) co integration approach. One assumption to be exist the selection proper lag length criteria before the JJ (1990) approach. In this research 1 to 10 periods estimate the following criteria of VAR, lag. The best lag length considered when three results shows minimum values. Akaike Information Criterion (AIC), Hannan-Quinn Criterion (HQC) and Schwarz Information Criterion (SIC) shows 3rd period is a minimum value. Therefore, three 3 is the best lag length for this study.

Table. 4.4

VAR Lag Length Criteria

\begin{tabular}{cccc}
\hline Lag & AIC & SC & HQ \\
\hline 0 & 12.8110 & 12.8338 & 12.8195 \\
1 & 7.9675 & 8.3537 & 8.0350 \\
2 & 7.8661 & 8.2074 & 8.0386 \\
3 & $7.8531^{*}$ & $8.1495^{*}$ & $7.9925^{*}$ \\
4 & 7.8775 & 8.5374 & 8.1220 \\
5 & 7.8976 & 8.7168 & 8.2012
\end{tabular}




\begin{tabular}{cccc}
6 & 7.9266 & 8.9051 & 8.2892 \\
7 & 7.9354 & 9.0731 & 8.3570 \\
8 & 7.9612 & 9.2582 & 8.4418 \\
9 & 7.9774 & 9.4337 & 8.5171 \\
10 & 8.0063 & 9.6219 & 8.6050 \\
\hline
\end{tabular}

*Selected Lag Length

\subsection{Multivariate Co-integration Test}

Techniques that identify the log-term relationship among two or more variables. In this study, apply cointegration techniques under this study all the time series integrated of the same order. Johnson and Julius (1990) co-integration analysis recognize the degree to which two variable are sensitive to the same average price over a specific time horizon. It does not replicate the variables are move similar or opposite direction, instead of it tell us distance between them continue it over time. In a technique two test applied, that conformed the results of this analysis. The first Trace Statistics and the second Maximum Eigen value test. Table 4.5 and table 4.6 reports the result of multivariate co-integration analysis using JJ (1990) approach. The table 4.5 Trace Statistics shows p value is less than 0.05 that clearly shows there exist co-integration vector at 5\% level. The table 4.6 conform the multivariate cointegration. The results of table Maximum Eigen conform the results of table 4.5 Trace Statistics that there occur multivariate co-integration vector at 5\% level. Therefore, the basis of JJ(1990) multivariate co- integration technique, according to researcher knowledge long run relationship exist among GAAPETR and other control and explanatory variables.

Table. 5

Multivariate Co-Integration Test (Trace Statistics)

\begin{tabular}{lcccc}
\hline Hypothesized & Eigenvalue & Trace Statistics & Critical Value & Prob.** \\
Lag Length=1 & & & 125.615 & 0.0001 \\
\hline None * & 0.13631 & 1042.38 & 95.7537 & 0.0001 \\
At most $1 *$ & 0.10699 & 797.365 & 69.8189 & 0.0001 \\
At most $2 *$ & 0.09872 & 608.16 & 47.8561 & 0.0001 \\
At most $3 *$ & 0.08487 & 434.373 & 29.7971 & 0.0001 \\
At most $4 *$ & 0.07097 & 286.085 & 15.4947 & 0.0001 \\
At most $5 *$ & 0.05807 & 163.01 & 3.84147 & 0.0001 \\
\hline At most $6 *$ & 0.03697 & 62.9852 & & \\
\hline
\end{tabular}

Trace test indicates 7 co-integrating eqn(s) at the 0.05 level

* denotes rejection of the hypothesis at the 0.05 level

**MacKinnon-Haug-Michelis (1999) p-values

Table. 6

Multivariate Co-Integration Test (Max-Eigen Value Statistics)

\begin{tabular}{lcccc}
\hline $\begin{array}{l}\text { Hypothesized } \\
\text { Lag Length=1 }\end{array}$ & Eigenvalue & Trace Statistics & $\begin{array}{c}\text { Critical Value } \\
5 \%\end{array}$ & Prob.** \\
\hline None $*$ & 0.13631 & 245.012 & 46.2314 & 0.0001 \\
At most $1 *$ & 0.10699 & 189.206 & 40.0776 & 0.0001 \\
At most $2 *$ & 0.09872 & 173.787 & 33.8769 & 0.0001 \\
At most $3 *$ & 0.08487 & 148.288 & 27.5843 & 0.0001 \\
At most $4 *$ & 0.07097 & 123.075 & 21.1316 & 0.0001 \\
At most $5 *$ & 0.05807 & 100.024 & 14.2646 & 0.0001
\end{tabular}




\begin{tabular}{l} 
At most $6 * 0.03697$ \\
\hline Max-eigenvalue test indicates 7 co-integrating eqn(s) at the 0.05 level \\
$*$ denotes rejection of the hypothesis at the 0.05 level \\
$* *$ MacKinnon-Haug-Michelis (1999) p-values
\end{tabular}

\subsection{Causality Test}

It is a theorem that say when co-integration occur among the variables with time series data analysis then granger causality essentially exist as a minimum unidirectional or bidirectional. All finding of granger causality test display the table 7 . This test conformed by all the time series p value is 0.05 or researcher reject the null hypothesis at 5\% of confidence. The results of blow table 7 show that unidirectional causality exist among GAAPETR, CE capital expenditure, DIV corporate diversification, FP firm profitability and LEV leverage and MBR market to book ratio have no causality. Though the $p$ vale is greater than to 0.05 ( $p>0.05$ ) between GAAPET, LEV and MBR. It mean GAAPETR does not Granger Cause among leverage and market to book ratio.

Table. 7

Pairwise Granger Causality Test

\begin{tabular}{lcccc}
\hline Null Hypothesis: & Obs & F-Statistic & Prob. & Inference \\
\hline GAAPETR does not Cause CE & \multirow{2}{*}{1667} & 2.2276 & 0.0142 & Unidirectional \\
CE does not Cause GAAPETR & & 0.9607 & 0.4760 & Causality \\
GAAPETR does not Cause DIV & 1667 & 0.7887 & 0.6398 & Unidirectional \\
DIV does not Cause GAAPETR & & 1.8265 & 0.0515 & Causality \\
GAAPETR does not Cause FP & \multirow{2}{*}{1667} & 3.0764 & 0.0007 & Unidirectional \\
FP does not Cause GAAPETR & & 0.9506 & 0.4852 & Causality \\
LEV does not Cause GAAPETR & \multirow{2}{*}{0.467} & 0.4291 & 0.933 & No Causality \\
GAAPETR does not Cause LEV & & 1.0793 & 0.3745 & \\
MBR does not Cause GAAPETR & \multirow{2}{*}{0.967} & 0.9322 & 0.5021 & No Causality \\
GAAPETR does not Cause MBR & & 0.8201 & 0.6092 & \\
\hline
\end{tabular}

\subsection{Variance Decomposition Test}

It is a multivariate analysis of classical statistics that show uncovering simplifying structure of large set of variables. Moreover, it shows the brief information of every variables that explain with other variables in auto regression. Variance decomposition show how much dependent variable is lagged by its individual variance. Table 8 reported the variance decomposition of GAAPETR with the change on itself and with the change of other variables CE, DIV, FP, LEV and MBR. In this study, results shows that the variation of GAAPETR is mostly to its energetic behavior. In table 8 variance decomposition show the GAAPETR, looks like exogenous since most of the shocks due to it is on variation. Whereas, the above table results reports that the variation of firm profitability is 1.63 in 10 period and market to book ratio is 0.0488 . Furthermore corporate diversification show highly variation 4.1657 with GAAPETR. It shows that corporate diversification is more variation rather than other variable with GAAPETR.

Table. 8

Variance Decomposition of GAAPETR:

\begin{tabular}{cccccccc}
\hline Period & S.E. & CE & DIV & FP & GAAPETR & LEV & MBR \\
\hline 1 & 0.7906 & 2.6234 & 0.7946 & 0.9261 & 95.6271 & 0.0000 & 0.0000 \\
2 & 0.9252 & 2.2418 & 1.0526 & 1.4032 & 95.1252 & 0.0026 & 0.0121
\end{tabular}




\begin{tabular}{cccccccc}
3 & 1.0191 & 2.4075 & 1.4241 & 1.4479 & 94.4277 & 0.0029 & 0.0133 \\
4 & 1.0766 & 2.5109 & 1.8327 & 1.5503 & 93.6688 & 0.0044 & 0.0148 \\
5 & 1.1152 & 2.6343 & 2.2576 & 1.5844 & 92.9431 & 0.0059 & 0.0205 \\
6 & 1.1417 & 2.7386 & 2.6810 & 1.6108 & 92.2518 & 0.0078 & 0.0267 \\
7 & 1.1604 & 2.8251 & 3.0910 & 1.6234 & 91.6185 & 0.0098 & 0.0333 \\
8 & 1.1738 & 2.8937 & 3.4783 & 1.6302 & 91.0474 & 0.0118 & 0.0393 \\
9 & 1.1837 & 2.9466 & 3.8376 & 1.6327 & 90.5408 & 0.0138 & 0.0445 \\
10 & 1.1911 & 2.9866 & 4.1657 & 1.6329 & 90.0966 & 0.0157 & 0.0489 \\
\hline
\end{tabular}

\subsection{Impulse Response Function}

IRF or impulse response function is an important function in econometric analysis. The most important purpose of IRF is to describe evolution of variables in reaction to a shock in one or more variables along a specified time horizon. IRF is a function that use for examine the interactions among variables in VAR vector autoregressive mode. IRF reports the shocks of variables hitting the systems, structural information use to specify the shocks that are comparative for specific economic problems because it's not clear which shock are relative for specific problem. Therefore, IRF impulse response function are discussed structural information of corporate diversification and tax avoidance. Beside that IRF, display the graphs that show the speed of adjustment. Figure 1 display the impulse response of GAAPETR towards the impulse of CE capital expenditure, DIV corporate diversification, FP firm profitability, LEV leverage and MBR market to book ratio. It clearly shows the major change in GAAPETR due to its own behavior. The researcher point of view it is disturb by due to its on innovation like exogenous. Moreover, other variables are also create positive and negative influence with GAAPETR.

Figure. 1

Impulse Response Function

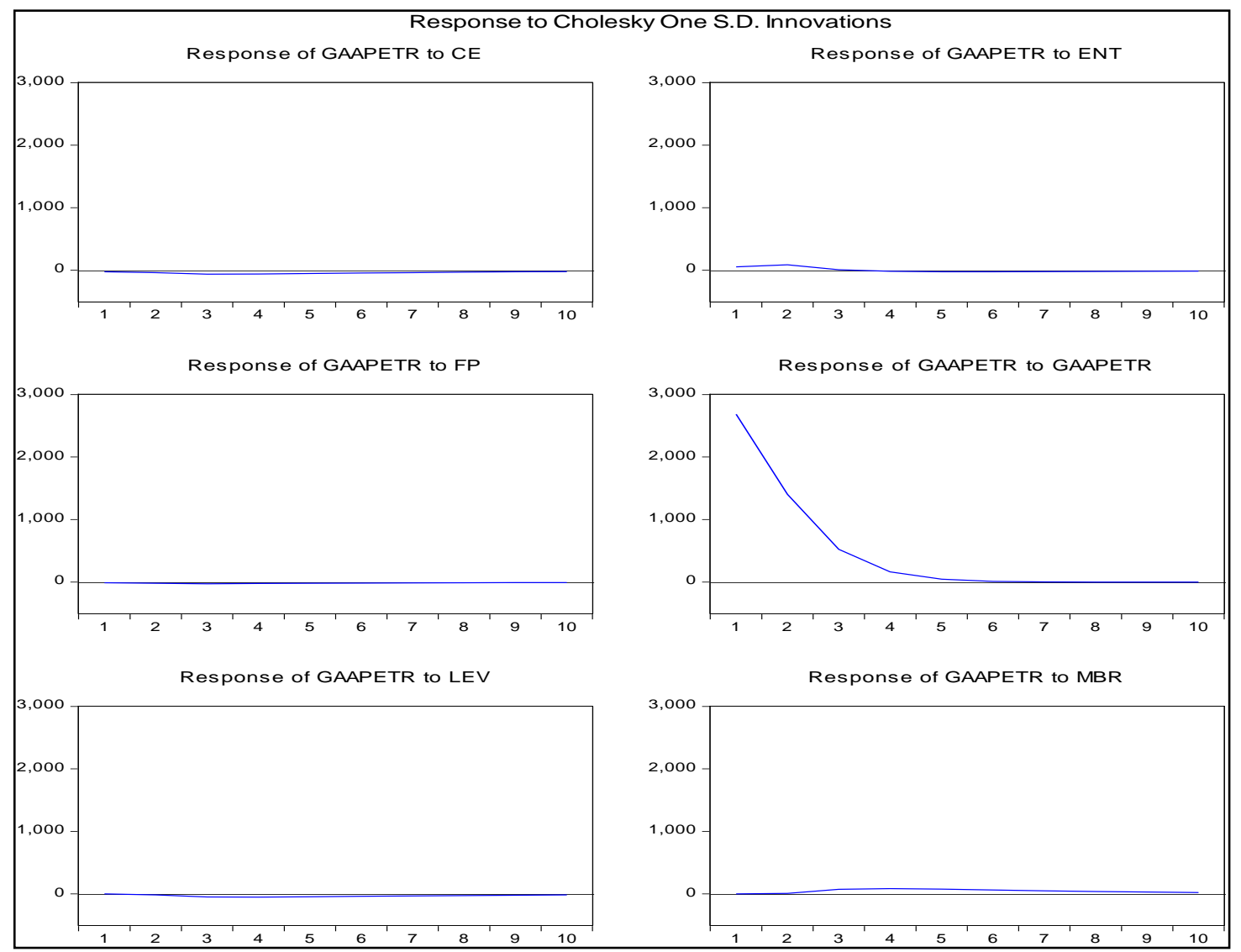




\section{Discussion and Conclusion}

As perspective of CEO ownership in stand-alone firms and diversified firms Anderson, Bates, Bizjak, \& Lemmon, (2000) and Hoechle et al., (2012) investigate lower ownership of CEO pay performance sensitivity. Dyreing et al., (2010) documented that CEO of the company play an important role for decision and determination of tax avoidance. Low powered of CEO and low incentives encourage managers to engage less tax avoidance activities (Desai \& Dharmapala, 2006). Zheng, (2017) persuading that weak insider controls may results in low level of tax avoidance practices rather than stand-alone firms. Therefore, on the basis of CEO ownership, outside checking and insider controls designate that firms diversified many segments engage in fewer tax avoidance activities rather than which firms have online one segment.

This study investigates the relationship of corporate diversification and tax avoidance. For sample selection study use the 22 different sectors and select 129 companies based on availability of data. The time horizon of this study is 13 years started from 2006 to 2018 on annual basis. Study uses GAAPETR (tax expense / pre-tax income) to measure the corporate tax avoidance besides entropy-index use for corporate diversification. To identify the relationship between corporate diversification and corporate tax avoidance study apply Johnson and Julius (1990) multivariate co-integration analysis. Results shows a significant relationship exist among corporate diversification and tax avoidance. The agency theory argues that diversified firm have weak corporate governance mechanism and that mechanism disrupts the relationship between the (Principals) shareholders and (Agents) executives. This type of problems create agency cost and it leads to managers that less aggressive about firm value through tax avoidance. Based on agency theory, the diversified firm have less involves in tax avoidance strategies rather than stand-alone firms.

The results shows the relationship between DIV (corporate diversification) and GAAPETR (tax payment) is positive, that means the diversified firms have involved more tax payments not tax avoidance practices. The results of co-integration analysis Trace test and Max-Eigen value statistics support the trace test. Finally, in the past many researchers work on corporate diversification with different factors (Wiersema, \& Bowen, 2008; Bhatia \& Thakur, 2018; Smith et al., 2018). There are rare studies on corporate diversification and tax avoidance strategies (Zheng, S. 2017). This study examine the long run relationship between corporate diversification and tax avoidance developed economies to emerging economies. In addition, it extend the debate on the association between company diversification and tax avoidance of developed countries to emerging countries. Finally, study is helpful for regulatory bodies, tax authorities and federal board of revenue (FBR) to take decisions and create certain mechanism for tax collection.

\section{Policy Implication and Future Direction}

This study suggested that tax authorities needs to encourage the manager's to show the potential advantages of corporate diversification strategies so these strategies generate positive signals for new and existing potential investors, shareholders and stakeholders by improve the tax disclosure mechanism. The findings indicate that tax authorities encourage the managers that corporate diversification may be used as a tool to reduce tax avoidance practices. While managing the agency problem like over investment, the results demonstrate that managerial discrepancy can be controlled, and therefore corporate diversification techniques are more useful in regulating tax avoidance practices.

As a future research direction, this study suggest that moderators can be used such as corporate governance dimensions, social responsibility in the relation between corporate diversification and tax avoidance. For future researcher can apply panel data analysis with probability sampling e.g. random or simple random sampling.

\section{References}

Aggarwal, R. K., \& Samwick, A. A. (2003). Why do managers diversify their firms? Agency reconsidered. The Journal of Finance, 58(1), 71-118. 
Akben Selçuk, E. (2015). Corporate diversification and firm value: evidence from emerging markets. International Journal of Emerging Markets, 10(3), 294-310.

Anderson, R. C., Bates, T. W., Bizjak, J. M., \& Lemmon, M. L. (2000). Corporate governance and firm diversification. Financial management, 5-22.

Annuar, H. A., Salihu, I. A., \&Obid, S. N. S. (2014). Corporate ownership, governance and tax avoidance: An interactive effect. Procedia-Social and Behavioral Sciences, 164, 150-160.

Armstrong, C. S., Blouin, J. L., Jagolinzer, A. D., \&Larcker, D. F. (2015). Corporate governance, incentives, and tax avoidance. Journal of Accounting and Economics, 60(1), 1-17.Berle, A., \& Means, G. (1932). Private property and the modern corporation. New York: Macmillan.

Bhatia, A., \& Thakur, A. (2018). Corporate diversification and firm performance: an empirical investigation of causality.International Journal of Organizational Analysis, 26(2), 202-225.

Chakrabarti, A., Singh, K., \& Mahmood, I. (2007). Diversification and performance: evidence from East Asian firms. Strategic Management Journal, 28(2), 101-120.

Chen, L., \& Zhao, X. (2006). On the relation between the market-to-book ratio, growth opportunity, and leverage ratio.Finance Research Letters, 3(4), 253-266.

Cheng, Q., Jiao, J., Chen, H., \& Xu, F. (2019). Application of Impulse Response Method in Identifying the Causes of Gold Price Fluctuation. Journal homepage: http://iieta. org/Journals/isi, 24(1), 6166.

Chircop, J., Fabrizi, M., Ipino, E., \& Parbonetti, A. (2018). Does social capital constrain firms' tax avoidance? Social Responsibility Journal, 14(3), 542-565.

Davis, A. K., Guenther, D. A., Krull, L. K., \& Williams, B. M. (2015). Do socially responsible firms pay more taxes?. The accounting review, 91(1), 47-68.

Deng, S. E., Elyasiani, E., \& Mao, C. X. (2007). Diversification and the cost of debt of bank holding companies. Journal of Banking \& Finance, 31(8), 2453-2473.

Denis, D. J., Denis, D. K., \& Sarin, A. (1997). Agency problems, equity ownership, and corporate diversification. The Journal of Finance, 52(1), 135-160.

Desai, M. A., \& Dharmapala, D. (2006). Corporate tax avoidance and high-powered incentives. Journal of Financial Economics, 79(1), 145-179.

Desai, M. A., \& Dharmapala, D. (2009). Corporate tax avoidance and firm value. The review of Economics and Statistics, 91(3), 537-546.

Duan, T., Ding, R., Hou, W., \& Zhang, J. Z. (2018). The burden of attention: CEO publicity and tax avoidance. Journal of Business Research, 87, 90-101.

Dyreng, S. D., Hanlon, M., \& Maydew, E. L. (2008). Long-run corporate tax avoidance. the accounting review, 83(1), 61-82.

Falope, O. I., \& Ajilore, O. T. (2009). Working capital management and corporate profitability: evidence from panel data analysis of selected quoted companies in Nigeria. Research journal of business management, 3(3), 73-84.

Francis, S. J., \& Ganeshamoorthy, M. (2017). Impact of Major Macroeconomic Variables on Stock Prices in Sri Lanka: An Econometric Analysis. Papers on Peace, Reconciliation and Development Challenges, 126.

Gallemore, J., \& Labro, E. (2015). The importance of the internal information environment for tax avoidance. Journal of Accounting and Economics, 60(1), 149-167.

Graham, J. R., Hanlon, M., Shevlin, T., \& Shroff, N. (2013). Incentives for tax planning and avoidance: Evidence from the field. The Accounting Review, 89(3), 991-1023.

Hanlon, M., \& Heitzman, S. (2010). A review of tax research. Journal of Accounting and 
Economics, 50(2-3), 127-178.

Hoechle, D., M. Schmid, I. Walter, and D. Yermack. 2012. How much of the diversification discount can be explained by poor corporate governance? Journal of Financial Economics 103, 41-60.

Huseynov, F., \& Klamm, B. K. (2012). Tax avoidance, tax management and corporate social responsibility. Journal of Corporate Finance, 18(4), 804-827.

Jensen, M. C., \& Meckling, W. H. (1976). Theory of the firm: Managerial behavior, agency costs, and ownership structure.Journal of financial economics, 3(4), 305-360.

Kang, J. (2013). The relationship between corporate diversification and corporate social performance. Strategic Management Journal, 34(1), 94-109.

Kenny, P. (2002). Australian Taxation, Ethics, and Social Capital. Business and Professional Ethics Journal, 21(3/4), 109-127.

Khanchel El Mehdi, I., \& Seboui, S. (2011). Corporate diversification and earnings management. Review of Accounting and Finance, 10(2), 176-196.

Kirina, L. S., \& Nazarova, N. A. (2017, July). Tax Planning as a Basis of the System of Corporate Tax Management. In International Conference on Humans as an Object of Study by Modern Science (pp. 476-484). Springer, Cham.

Koh, Y.S. (2007), “A study on corporate tax avoidance”, PhD dissertation, Yonsei University, Seoul

Kweon, S. C., Kang, Y. O., Kim, C. H., \& Kim, J. H. (2009). An empirical study on relationship between tax avoidance and enterprise characters' variables. Korea International Accounting Review, 26, 189-210.

Landry, S., Deslandes, M., \& Fortin, A. (2013). Tax aggressiveness, corporate social responsibility, and ownership structure.

Lanis, R., \& Richardson, G. (2011). The effect of board of director composition on corporate tax aggressiveness. Journal of Accounting and Public Policy, 30(1), 50-70.

Lazaridis, I., \& Tryfonidis, D. (2006). Relationship between working capital management and profitability of listed companies in the Athens stock exchange. Journal of financial management and analysis, 19(1) pp. 26-35.

Lisowsky, P. (2010). Seeking shelter: Empirically modeling tax shelters using financial statement information. The Accounting Review, 85(5), 1693-1720.

Mashaiekhi, B., Seyyedi, J. (2015), corporate governance and tax avoidance. Journal of Accounting and Economics, 20, 83-103.

Masripah, M., Diyanty, V., \& Fitriasari, D. (2017). Controlling Shareholder and Tax Avoidance: Family Ownership and Corporate Governance. INTERNATIONAL RESEARCH JOURNAL OF BUSINESS STUDIES, 8(3).

Matsusaka, J. G. (2001). Corporate diversification, value maximization, and organizational capabilities. The Journal of Business, 74(3), 409-431.

McClure, R., Lanis, R., Wells, P., \& Govendir, B. (2018). The impact of dividend imputation on corporate tax avoidance: the case of shareholder value. Journal of Corporate Finance, 48, 492514.

Morck, R., 2005. How to eliminate pyramidal business groups: the double taxation of inter-corporate dividends and other incisive uses of tax policy. In: Poterba, J.(Ed.), Tax Policy and the Economy. University of Chicago Press, Chicago, pp. 135-179.

Olibe, K. O., Rezaee, Z., Flagg, J., \& Ott, R. (2019). Corporate diversification, debt maturity structures, and firm value: The role of geographic segment data. The Quarterly Review of Economics and Finance. 
Picur, R.D. and Riahi-Belkaoui, A. (2006), "The impact of bureaucracy, corruption and tax compliance" Review of Accounting and Finance, Vol. 5 No. 2, pp. 174-180.

Rego, S. O., \& Wilson, R. (2012). Equity risk incentives and corporate tax aggressiveness. Journal of Accounting Research, 50(3), 775-810.

Richardson, G., Lanis, R., \& Taylor, G. (2015). Financial distress, outside directors and corporate tax aggressiveness spanning the global financial crisis: An empirical analysis. Journal of Banking \& Finance, 52, 112-129.

Sam, C. Y. (2010). Exploring the link between tax evasion and the underground economy. Pakistan Economic and Social Review, 167-182.

Sarwar, B., Xiao, M., Husnain, M., \& Naheed, R. (2018). Board financial expertise and dividendpaying behavior of firms: New insights from the emerging equity markets of China and Pakistan. Management Decision, 56(9), 1839-1868.

Scholes, M., Wolfson, M., Erickson, M., Maydew, E., \& Shevlin, T. (2005). Tax and business strategy: A planning approach. 3rd Edition, Pearson Prentice Hall, Upper saddle river, NJ.

Shah, A., Muhammad, S., Husnain, M., \& Ali, A. (2012). Is Pakistani Equity Market Integrated to the Equity Markets of Group of Eight (G8) Countries? An Empirical Analysis of Karachi Stock Exchange. Romanian Economic Journal,15(45).

Shin, H. H., \& Soenen, L. (1998). The efficiency of working capital management and corporate profitability. Financial practice and education, 8, 37-45.

Smith, A. (1776). 1986. The wealth of nations. Books 1-3.

Smith, M. J. (2002). Ex-ante and ex-post discretion over arm's length transfer prices. The Accounting Review, 77(1), 161-184.

Wiersema, M. F., \& Bowen, H. P. (2008). Corporate diversification: The impact of foreign competition, industry globalization, and product diversification. Strategic Management Journal, 29(2), 115-132.

Wilson, R. J. (2009). An examination of corporate tax shelter participants. The Accounting Review, 84(3), 969-999

Zheng, S. (2017). Can corporate diversification induce more tax avoidance? Journal of Multinational Financial Management, 41, 47-60.

Zimmerman, J. L. (1983). Taxes and firm size. Journal of accounting and economics, 5, 119 
APPENDIX A Impulse Response Function (All Variables)

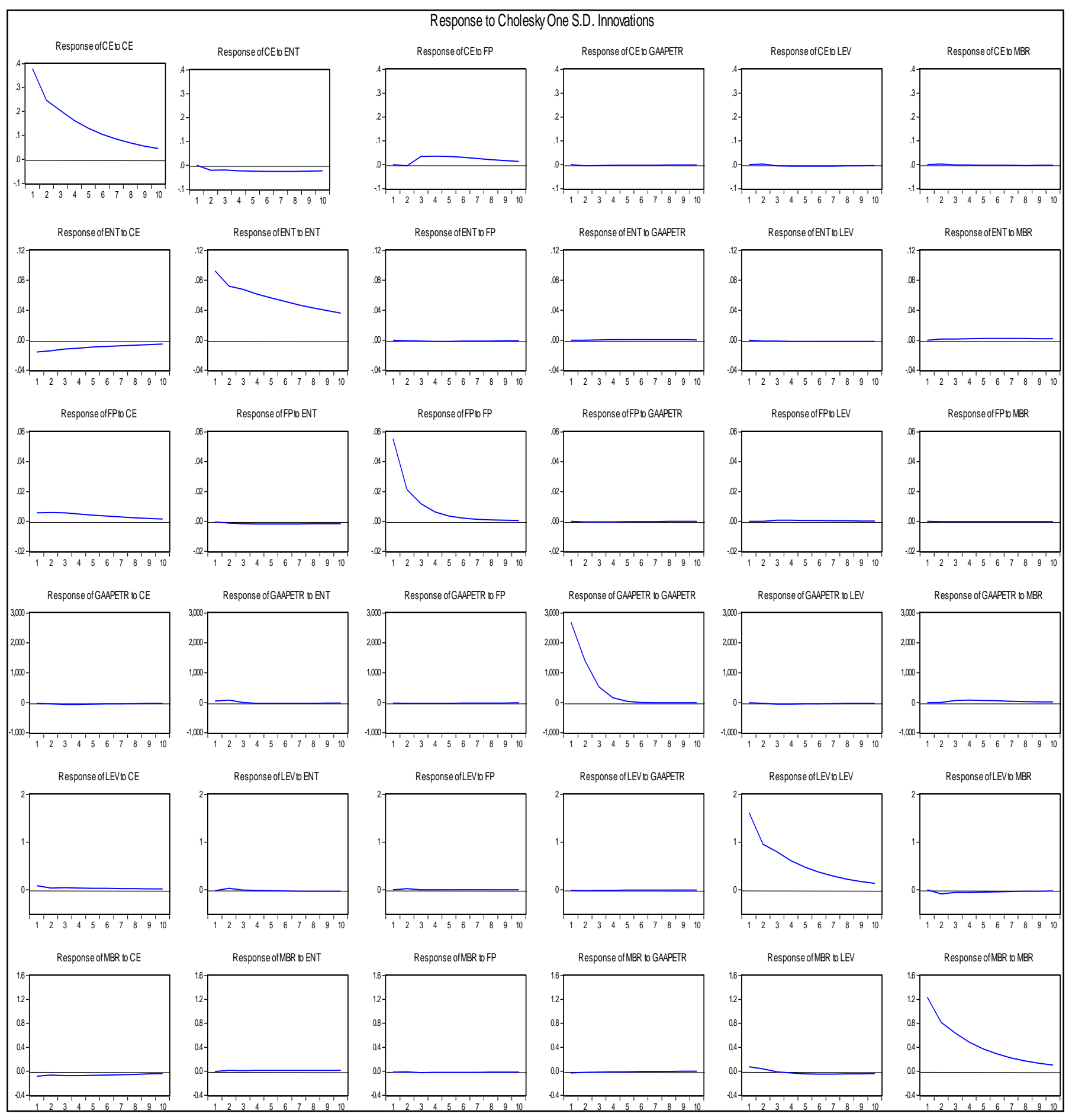

